\title{
Examination of the effect of pelleted poultry manure products on a sunflower test plant in a laboratory model experiment
}

\author{
Edit Gorliczay $^{1}$ - Nikolett Szöllösi ${ }^{1}$ - Nikolett Éva Kiss ${ }^{2}$ - Florence Tóth ${ }^{3}$ - János Tamás ${ }^{1}$ - \\ Péter Tamás Nagy ${ }^{1}$ \\ ${ }^{1}$ University of Debrecen, Faculty of Agricultural and Food Sciences and Environmental Management, Institue of Water and Environmental \\ Management \\ ${ }^{2}$ University of Debrecen, Faculty of Agricultural and Food Sciences and Environmental Management, Doctoral School of Animal Husbandry \\ ${ }^{3}$ University of Debrecen, Faculty of Agricultural and Food Sciences and Environmental Management, Doctoral School of Nutrition and Food \\ Sciences \\ edit.gorliczay@agr.unideb.hu
}

\section{SUMMARY}

Sunflower (Helianthus annuus L.) is one of the most important oil plants in Hungary, with a sown area of more than 627.000 ha in 2019. Sunflower cultivation is primarily important for use in the oil industry, but its role in feed and beekeeping cannot be neglected either. Sunflower adapts well to different production areas in terms of soil demand, yet, as important fact, it must be grown on soils with poorer conditions with intensive nutrient replenishment. From the agri-environmental point of view, in addition to the use of pelleted poultry manure products, which are also new to the consumer market, is of paramount importance. Their advantages include a wide range of nutrients as well as a soil structure improving effect.

In our research, we investigated the starter effect of pelleted poultry manure products applied at different doses (200 $\mathrm{kg} \mathrm{ha}^{-1}$ and $400 \mathrm{~kg}$ ha $\left.\mathrm{a}^{-1}\right)$ on sandy soil with humus using a sunflower plant. The aim of our research to investigate the effect of using pelleted fertilizer products as starter fertilizers on sunflower plant germination, and investigate the effect of poultry manure products on soils.

Based on our results, it can be stated that the pigment content (chlorophyll and carotenoid content) was positively influenced by the higher dose treatments $\left(400 \mathrm{~kg} \mathrm{ha}^{-1}\right)$, thus increasing the photosynthetically active leaf area. Compared to the control, the carotenoid content in the test plants of the treatments increased, and the differences of this treatment proved to be significant $(p<0.05)$. Our experiments supported the beneficial effect of pelleted poultry manure-based products in the soil-plant system.

Keywords: manure; sunflower; pelleted manure; soil; model experiment

\section{INTRODUCTION}

In north-eastern Hungary, concentrated poultry farming (broiler, goose, duck farming) produces large amounts of manure, which can endanger the environment - mainly water bases and air - however, in the absence of organic fertilizers the negative nutrient balance of the region's soils deteriorates further (AKI, 2012). Until the first third of the last century, nutrients abstracted from crop production were replaced by organic fertilizers in Hungary (Sárdi, 2011), however, after 1990 the number of nutrients introduced into the soil by organic fertilizers was halved due to the halving of livestock. In agriculture, manure is used primarily, which can also be used for soil improvement, and it can be used to replace high-cost fertilizers in crop production systems. In crop production systems, it is not enough to replace the nutrients extracted from the crop with fertilization and to satisfy the missing nutrient needs with fertilizers, as the physicochemicalbiological effects of organic fertilizers on the soil cannot be replaced (Hoffmann, 2008). Among the effects of manures as well as the increase of cation binding capacity, soil structure construction and the promotion of microbial activity is particularly important (Pirkó and Tóth, 2017). As the organic matter content of the soil decreases, these functions may be impaired and the risk of other soil degradation processes may increase. Based on all this, the decrease of soil organic matter content is considered to be one of the most dangerous soil destruction processes at the global and European levels (Michéli et al., 2011).

Of the organic fertilizers, manure is particularly valuable, as its macro-and microelement content is of great importance in nutrient replenishment (Loch and Nosticzius, 2004). However, for organic fertilizers to be able to replace fertilizers, it is necessary to treat them in such a way that a significant part of their volatile nitrogen content does not escape as air pollutants. Manure processing is slowly being incorporated into agricultural practice, as in $2010 / 11$ only $7.8 \%$ of the resulting organic manure was treated by some process (aerobic or anaerobic fermentation) (Fogged et al., 2012). According to Brake (1992) and Haga (1999), one way to treat manure is composting, which increases the quality of raw manure and reduces the environmental risk from the application. During the composting process, the volume and weight of manure are reduced, pathogens and weed seeds are destroyed, unpleasant odors are reduced (Tiquia and Tam, 1998), and nutrients and organic matter are stabilized (Michel et al., 1996). One method of composting manure is Hosoya type composting. The Hosoya system is a technology based on intensive fermentation, created specifically for the treatment of manure. The system itself involves a three-phase process: two-phase aerobic fermentation, drying, and final drying (Georgakakis and Krintas, 2000). After Hosoya composting, the compost is supplemented with additives, so it can be used for nutrient replenishment like fertilizers. 


\section{MATERIALS AND METHODS}

The experiments and laboratory measurements were performed at the University of Debrecen, Research Center of Organic Matter. The characteristics of the soil used in the pot experiment are shown in Table 1 .
In the pot experiments, we used three types of BioFer products made from a mixture of composted poultry manure and chicken manure $\left(I_{1}\right)$. The characteristics of the pelleted manure are shown in Table 2.

Table 1. The characteristics of the sandy soil with humus

\begin{tabular}{|c|c|c|c|}
\hline Measured parameters & & Measured parameters & \\
\hline $\mathrm{pH}$ (KCl-extract) & 5.76 & Sodium-content $\left(\mathrm{mg} \mathrm{kg}^{-1}\right)$ (AL-extract) & 58.6 \\
\hline Plasticity index according to Arany $\left(\mathrm{K}_{\mathrm{A}}\right)$ & 30 & Magnesium-content $\left.\mathrm{mg} \mathrm{kg}^{-1}\right)$ (KCl-extract) & 157 \\
\hline Total water soluble salts (w/w\%) & 0.02 & Sulfur-content $\left(\mathrm{mg} \mathrm{kg}^{-1}\right)(\mathrm{KCl}$-extract $)$ & 6.43 \\
\hline Carbonate content (w/w\%) & $<0.100$ & $\begin{array}{c}\text { Manganese-content }\left(\mathrm{mg} \mathrm{kg}^{-1}\right) \text { (EDTA } \\
\text { extract) }\end{array}$ & 161 \\
\hline Organic carbon content (humus content) (w/w\%) & 1.57 & Zinc-content ( $\left.\mathrm{mg} \mathrm{kg}^{-1}\right)$ (EDTA extract) & 1.76 \\
\hline Phosphorus-pentoxide (mg kg$\left.{ }^{-1}\right)$ (AL-extract) & 176 & Copper-content (mg kg-1) (EDTA extract) & 4.73 \\
\hline Potassium-oxide ( $\left.\mathrm{mg} \mathrm{kg}^{-1}\right)$ (AL-extract) & 351 & Organic nitrogen $(\mathrm{w} / \mathrm{w} \%)$ & 0.106 \\
\hline Nitrate $\left(\mathrm{mg} \mathrm{kg}^{-1}\right)(\mathrm{KCl}$-extract$)$ & 12.3 & & \\
\hline
\end{tabular}

Table 2. The characteristics of the pelletized products

\begin{tabular}{ccc}
\hline Bio-Fer Humin Plus product & Bio-Fer P+K “C” product & Bio-Fer P+K product \\
\hline $50 \mathrm{w} / \mathrm{w} \%$ mixture of composted manures & $60 \mathrm{w} / \mathrm{w} \%$ mixture of composted manures & $60 \mathrm{w} / \mathrm{w} \%$ mixture of composted manures \\
$20 \mathrm{w} / \mathrm{w} \%$ meat flour & $15 \mathrm{w} / \mathrm{w} \%$ meat flour & $15 \mathrm{w} / \mathrm{w} \% \mathrm{meat}$ flour \\
$20 \mathrm{w} / \mathrm{w} \%$ superphosphate & $15 \mathrm{w} / \mathrm{w} \%$ superphosphate & $15 \mathrm{w} / \mathrm{w} \%$ superphosphate \\
$10 \mathrm{w} / \mathrm{w} \%$ dudarit & $10 \mathrm{w} / \mathrm{w} \% \mathrm{~K}_{2} \mathrm{SO}_{4}$ & $10 \mathrm{w} / \mathrm{w} \% \mathrm{~K}_{2} \mathrm{SO}_{4}$ \\
$0,4 \% \mathrm{ZnSO}_{4}$ & $0,4 \% \mathrm{ZnSO}_{4}$ \\
\hline
\end{tabular}

These products were mixed into the pots in two doses $\left(200 \mathrm{~kg} \mathrm{ha}^{-1}\right.$ and $\left.400 \mathrm{~kg} \mathrm{ha}^{-1}\right)$. The amount of pellets used for the two doses was calculated on an area-by-area basis per hectare. $0.091 \mathrm{~g}$ of pellets were mixed into $1 \mathrm{~kg}$ of soil for a dose of $200 \mathrm{~kg} \mathrm{ha}^{-1}$ and $0.182 \mathrm{~g}$ for a dose of $400 \mathrm{~kg} \mathrm{ha}^{-1}$. The experiments were performed with a water capacity level of $60 \%$. When setting up the experiment, 5-5 sunflower seeds were placed in each pot at a depth of $5 \mathrm{~cm}$, and the water capacity level was set to $60 \%$. The pot experiment was completed on day 21 , during which the following parameters were measured: shoot length $(\mathrm{cm})$, root length $(\mathrm{cm})$, wet biomass weight $(\mathrm{g})$, total chlorophyll and carotenoid content $\left(\mu \mathrm{g} \mathrm{g}^{-1}\right)$. The determination of total chlorophyll, and carotenoid content from fresh plant samples were homogenized with $80 \%$ acetone and quartz sand, and then settled in a HETTICH ROTOFIX 32A centrifuge at 3 minutes at $3000 \mathrm{rpm}$. $2.5 \mathrm{ml}$ of the clear solution at the top of the centrifuge tubes were pipetted into a quartz cuvette and the absorbance of plant extracts was measured with a SECOMAN Anthelie Light II UV-VIS spectrophotometer at 470,644, and $663 \mathrm{~nm}$. Prior to the measurements, zero calibration was performed in all cases, using $80 \%$ acetone. We used the equation from Droppa et al. (2003) and we calculated the total chlorophyll content:

$$
\mathrm{CL}_{\mathrm{A}, \mathrm{B}}=\left(20.2 * \mathrm{~A}_{644}+8.02 * \mathrm{~A}_{663}\right) * \mathrm{~V} / \mathrm{w}
$$

where the factors in the above equation are:

$\mathrm{CL}_{\mathrm{A}, \mathrm{B}}=$ chlorophyll $\mathrm{A}$ and $\mathrm{B}\left(\mu \mathrm{g} \mathrm{g}^{-1}\right)$ (per gram of fresh weight)

$\mathrm{A}_{644}, \mathrm{~A}_{663}=$ the absorbance of 644 and 663 wavelength

$$
\begin{aligned}
& \mathrm{V}=\text { volume of liquid plant extract }(\mathrm{ml}) \\
& \mathrm{w}=\text { weight of fresh plant sample }(\mathrm{g})
\end{aligned}
$$

To calculate the carotenoid content we used the equation based on Lichtenthaler et al. (1983):

$$
\mathrm{CC}=\left(1000 * \mathrm{~A}_{470}-3.27 *\left(12.21 * \mathrm{~A}_{663}-2.81 * \mathrm{~A}_{644}\right)-104 *\left(20.13 * \mathrm{~A}_{644}-5.03 * \mathrm{~A}_{663}\right)\right) * \mathrm{~V} / \mathrm{w}
$$

where the factors in the above equation are:

$\mathrm{CC}=$ carotenoid content $\left(\mu \mathrm{g} \mathrm{g}^{-1}\right)($ per gram of fresh weight)
$\mathrm{A}_{470,663,644=}$ the absorbance of 470,663 and 644 wavelength

$\mathrm{V}=$ volume of liquid plant extract $(\mathrm{ml})$ $\mathrm{w}=$ weight of fresh plant sample $(\mathrm{g})$ 
Non-destructive measurements were performed in the 400-1000 nm wavelength range with an AvaSpec 2048 spectrometer, which was able to examine plant samples with a resolution of $0.566 \mathrm{~nm}$ and an accuracy of $1 \mathrm{~nm}$. The AvaSpec 2048 spectrometer consists of three parts: a spectrometer (detector), $8 \mu \mathrm{m}$ diameter fiber optics and, a halogen light source. In order to ensure accurate measurement and to eliminate the interfering effect of electromagnetic radiation caused by fluorescent lamps, the tests were performed in a closed laboratory cabinet (Riczu, 2015; Bökfi et al., 2016; Nagy et al., 2012). Four reflectance spectra were calculated from the plant samples, calculated from the average of 30 measurements, which was significant due to the measurement uncertainties resulting from the heterogeneity. The obtained results were processed using AvaSoft 8.0 and MS Office Excel.

\section{Statistical data evaluation methods}

Statistical analyzes were performed using $\mathrm{R}$ software in an $\mathrm{R}$ Studio user environment ( $\mathrm{R}$ Core Team, 2017). The Shapiro-Wilk normality test was used to examine the distribution of the data, and then the type of test to be used for further analyzes was selected as a function of the distribution. To verify statistical differences between different treatments, a one-way analysis of variance was used at a $\mathrm{p}<0.05$ level of significance level. In addition, a Pearson correlation matrix was constructed to prove the correlations between the studied parameters.

\section{RESULTS AND DISCUSSION}

The results obtained in the study of plant biomass are presented in Table 3 for each treatment. Based on the results of the plant biomass studies, it can be concluded that the treatments, especially the higher dose treatments, differ significantly for all three examined parameters compared to the control. Root length, stem length, and wet biomass mass were greater in each treatment than in the control. Stem length was most favorably affected by the $\mathrm{P}+\mathrm{K}$ " $\mathrm{C}$ " treatment of $400 \mathrm{~kg} \mathrm{ha}^{-1}$, which is the treatment and dose that is significantly different from the other treatments. The control differed significantly from the treated plants in terms of stem length, but this significance means that this treatment had the smallest plant stem length (19.89 $\mathrm{cm})$. In contrast, root length was significantly increased with Humin Plus $200 \mathrm{~kg} \mathrm{ha}^{-1}$. Statistical separation of treatments at $5 \%$ the significance level for uncertain root length and stem length. The value of LSD was 1.52 $\mathrm{cm}$ at the root length and $6.43 \mathrm{~cm}$ at the stem length. Wet biomass mass was increased the least by $\mathrm{P}+\mathrm{K}$ treatments. For wet biomass mass, there was no significant difference between the treated plants and the control, as evidenced by the LSD value $(\mathrm{LSD}=3.32$ $\mathrm{cm})$.

Table 3. Root and stem length and wet biomass mass of sunflower test plants

\begin{tabular}{cccc}
\hline Treatments & $\begin{array}{c}\text { Average root length } \pm \\
\text { standard deviation (cm) }\end{array}$ & $\begin{array}{c}\text { Average stem length } \pm \\
\text { standard deviation (cm) }\end{array}$ & $\begin{array}{c}\text { Wet biomass mass } \pm \text { standard } \\
\text { deviation }(\mathbf{g})\end{array}$ \\
\hline Control & $5.01 \pm 1.64 \mathrm{ab}$ & $19.89 \pm 6.88 \mathrm{~b}$ & $4.25 \pm 2.00 \mathrm{a}$ \\
Humin plus $200 \mathrm{~kg} \mathrm{ha}^{-1}$ & $6.46 \pm 0.98 \mathrm{a}$ & $23.51 \pm 3.10 \mathrm{ab}$ & $5.58 \pm 3.09 \mathrm{a}$ \\
Humin plus $400 \mathrm{~kg} \mathrm{ha}^{-1}$ & $4.82 \pm 0.05 \mathrm{ab}$ & $25.02 \pm 3.95 \mathrm{ab}$ & $6.18 \pm 0.98 \mathrm{a}$ \\
$\mathrm{P}+\mathrm{K} 200 \mathrm{~kg} \mathrm{ha}^{-1}$ & $6.04 \pm 0.44 \mathrm{ab}$ & $23.03 \pm 2.14 \mathrm{ab}$ & $5.55 \pm 1.98 \mathrm{a}$ \\
$\mathrm{P}+\mathrm{K} 400 \mathrm{~kg} \mathrm{ha}^{-1}$ & $5.50 \pm 0.91 \mathrm{ab}$ & $22.49 \pm 3.43 \mathrm{ab}$ & $4.45 \pm 1.98 \mathrm{a}$ \\
$\mathrm{P}+\mathrm{K}$ "C" $200 \mathrm{~kg} \mathrm{ha}^{-1}$ & $5.43 \pm 1.22 \mathrm{ab}$ & $23.22 \pm 5.76 \mathrm{ab}$ & $6.30 \pm 3.07 \mathrm{a}$ \\
$\mathrm{P}+\mathrm{K}$ "C" $400 \mathrm{~kg} \mathrm{ha}^{-1}$ & $4.53 \pm 1.13 \mathrm{~b}$ & $27.56 \pm 3.49 \mathrm{a}$ & $5.98 \pm 1.97 \mathrm{a}$ \\
\hline
\end{tabular}

$\mathrm{p}<0.05$

*there is no significant difference between the treatments indicated by the same letter

With sunflower, a good fertilizer reaction can be expected on sandy soils, which is also proved by our studies. Sunflower reacted better to the product in which, in addition to the composted poultry manure, meat flour, superphosphate and potassium and zinc supplementation are also present, as the NPK requirement of sunflower is 1:1:2 and the composted poultry manure has an excess of potassium and nitrogen too.

\section{Results of measurements of plant pigment content}

The development of chlorophyll content is influenced by several factors, such as the increasing nutrient supply. In the case of maize, previous research has shown that the increased nutrient supply increases the photosynthetically active leaf area of maize, and thus its yield (Bencze and Futó, 2017). When examining the chlorophyll content of sunflower, a tendency can be observed that the chlorophyll content increases with the effect of higher fertilizer doses compared to the control. 
Table 4. Evaluation of total chlorophyll and carotenoid content

\begin{tabular}{|c|c|c|}
\hline Treatments & $\begin{array}{c}\text { Total chlorophyll content ( } \mu \mathrm{g} \\
\left.\mathrm{g}^{-1}\right)\end{array}$ & $\begin{array}{c}\text { Total carotenoid content }(\mu \mathrm{g} \\
\left.\mathrm{g}^{-1}\right)\end{array}$ \\
\hline Control & $1411.37 \pm 807.75 b c$ & $270.31 \pm 176.18 b c$ \\
\hline Humin Plus $200 \mathrm{~kg} \mathrm{ha}^{-1}$ & $1459.91 \pm 100.86 b c$ & $296.09 \pm 19.16 b c$ \\
\hline Humin Plus $400 \mathrm{~kg} \mathrm{ha}^{-1}$ & $1290.43 \pm 282.59 b c$ & $260.68 \pm 52.74 \mathrm{c}$ \\
\hline $\mathrm{P}+\mathrm{K} 200 \mathrm{~kg} \mathrm{ha}^{-1}$ & $1221.81 \pm 181.63 \mathrm{c}$ & $252.13 \pm 31.17 \mathrm{c}$ \\
\hline $\mathrm{P}+\mathrm{K} 400 \mathrm{~kg} \mathrm{ha}^{-1}$ & $2525.24 \pm 590.63 \mathrm{a}$ & $511.78 \pm 109.58 \mathrm{a}$ \\
\hline $\mathrm{P}+\mathrm{K}$ "C" $200 \mathrm{~kg} \mathrm{ha}^{-1}$ & $1336.29 \pm 121.08 b c$ & $253.63 \pm 25.09 c$ \\
\hline $\mathrm{P}+\mathrm{K}$ "C" $400 \mathrm{~kg} \mathrm{ha}^{-1}$ & $1605.13 \pm 120.08 \mathrm{ab}$ & $345.98 \pm 53.59 \mathrm{ab}$ \\
\hline
\end{tabular}

The chlorophyll content of the control was also exceeded by the treatments Humin Plus $200 \mathrm{~kg} \mathrm{ha}^{-1}$, $\mathrm{P}+\mathrm{K} 400 \mathrm{~kg} \mathrm{ha}^{-1}$ and $\mathrm{P}+\mathrm{K}$ "C" $400 \mathrm{~kg} \mathrm{ha}^{-1}$. Compared to the control, the highest chlorophyll content was measured in the case of $\mathrm{P}+\mathrm{K} 400 \mathrm{~kg} \mathrm{ha}^{-1}(2525.24 \mu \mathrm{g} \mathrm{g}$ ${ }^{1}$ ), even the lowest total chlorophyll content was measured in the case of $\mathrm{P}+\mathrm{K} 200 \mathrm{~kg} \mathrm{ha}^{-1}(1113.61 \mu \mathrm{g} \mathrm{g}$ $\left.{ }^{1}\right)$. There is a significant difference in chlorophyll content between control and treated plants. Humin Plus $200 \mathrm{~kg} \mathrm{ha}^{-1}, \mathrm{P}+\mathrm{K} 400 \mathrm{~kg} \mathrm{ha}^{-1}$ and $\mathrm{P}+\mathrm{K}$ “C” $400 \mathrm{~kg} \mathrm{ha}^{-1}$ treatments had a good effect on the carotenoid content of sunflower compared to the control. Compared to the control, the highest carotenoid content was $\mathrm{P}+\mathrm{K} 400 \mathrm{~kg}$ $\mathrm{ha}^{-1}$, the lowest carotenoid content $\mathrm{P}+\mathrm{K} 200 \mathrm{~kg} \mathrm{ha}^{-1}$ and $\mathrm{P}+\mathrm{K}$ "C $\mathrm{C}$ " $200 \mathrm{~kg} \mathrm{ha}^{-1}$. There is a significant difference in carotenoid content between control and treated plants.
I also evaluated the correlations between the examined parameters, as well as their strength and direction, in Pearson's correlation matrix. Based on these, it can be said that I was able to show a weak $(\mathrm{r}=0.2-0.3)$ positive but not significant relationship between the examined parameters at the $5 \%$ significance level. There was a functional positive correlation $(\mathrm{r}=0.98)$ between the total chlorophyll and total carotenoid contents, suggesting a strong interaction between the two parameters.

I also evaluated the development of plant pigment content in the wavelength range of 400-1000 nm using a non-destructive, spectral method. The resulting reflectance curves were plotted per dose relative to the control. Figure 1 shows the reflectance values measured at a dose of $200 \mathrm{~kg} \mathrm{ha}^{-1}$ compared to the control.

Figure 1. Evaluation of reflectance at a dose of $200 \mathrm{~kg} \mathrm{ha}^{-1}$ compared to the control

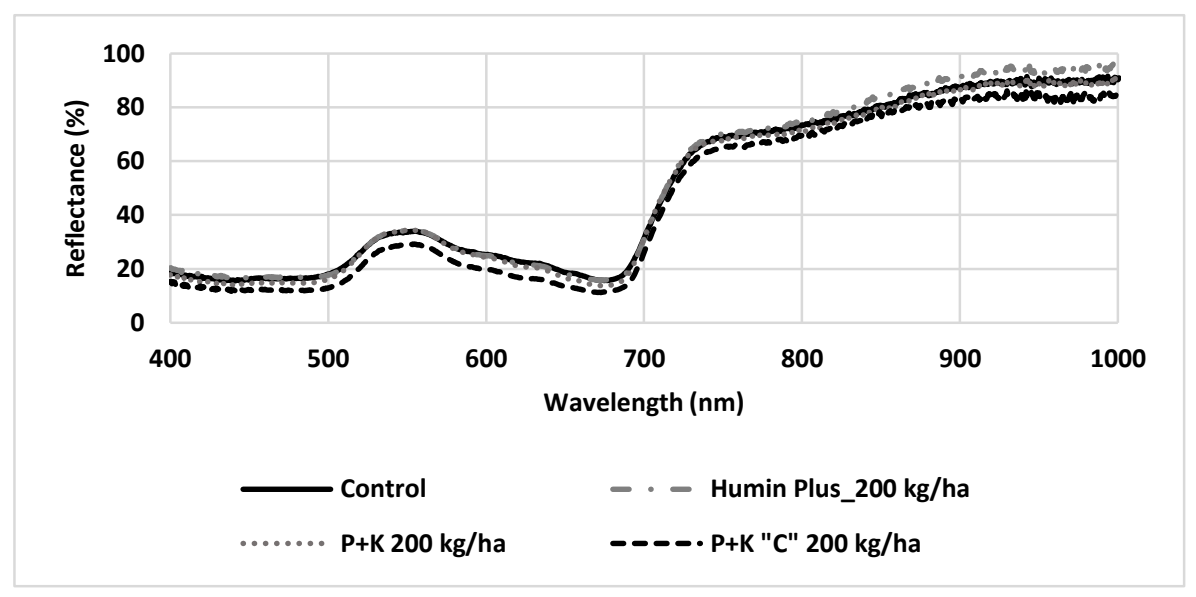

At a dose of $200 \mathrm{~kg} \mathrm{ha}^{-1}$ (Figure 1), it can be seen that the reflectance of the control was higher than that of the treated plants. This trend develops up to the Red Edge range (670-720 nm), and then in the NIR range, the reflectance curves of the control and treated plants cannot be clearly distinguished. In both the visible (VIS) and NIR ranges, the $\mathrm{P}+\mathrm{K}$ " $\mathrm{C}$ " treatment had the lowest reflectance, which means that the leaves of the plants were darker as a result of the treatment, and thus their reflectance was lower. In the carotenoid-sensitive wavelength range $(520-580 \mathrm{~nm})$, the control had a higher reflectance, suggesting an increase in carotenoid content, which is one of the symptoms of yellowing of the plant and presumably nutrient deficiency. In the case of these measurement results, it cannot be proved that if the chlorophyll content increases, the carotenoid content decreases. In contrast, Kopsell et al. (2007) show that higher total carotenoids can be explained by 
higher fertilizer doses and higher nitrogen uptake by the plant.

Figure 2 shows the reflectance values measured at a dose of $400 \mathrm{~kg} \mathrm{ha}^{-1}$ compared to the control.

Based on the reflectance of the $400 \mathrm{~kg} \mathrm{ha}^{-1}$ treatments compared to the control, the reflectance of the control was higher compared to the reflectance of the pellet-treated plants. In addition, in the case of the control, it was also observed that the reflectance was high in the wavelength range sensitive to carotenoid content $(520-580 \mathrm{~nm})$, which also indicates that the chlorophyll content was lower in the case of increased carotenoid content. This trend can be explained by the fact that the plants treated with pellets had a better nitrogen supply and thus a chlorophyll content, which resulted in a darker color of the plant and thus a lower reflectance.

Figure 2. Evaluation of reflectance at a dose of $400 \mathrm{~kg} \mathrm{ha}^{-1}$ compared to the control

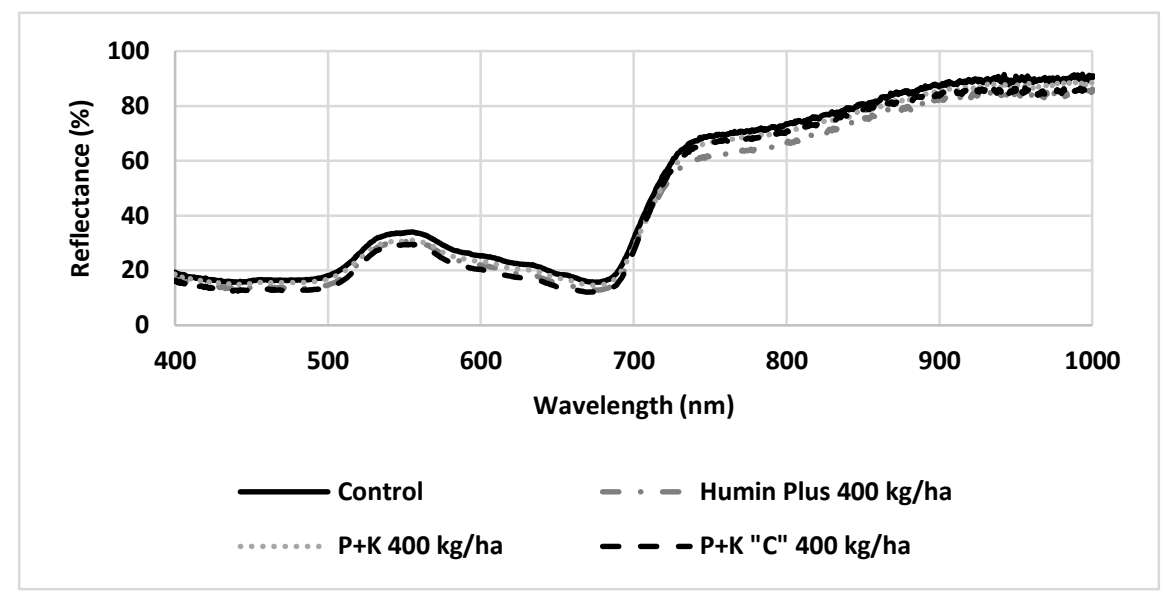

These results are also supported by the results obtained by Nagy (2017), who examined the effects of different bacterial-based biofertilizer treatments on sunflower hybrids. Based on his results, plants begin to break down chlorophyll in addition to proteins under stress, which can even be a lack of a nutrient. Based on these, if the plants have a poor nutrient supply, the chlorophyll content is lower and their reflectance is higher. The absorption maximum of chlorophyll was determined by Bratek et al. (2013) results in the wavelength range of 600-700 $\mathrm{nm}$, as can be observed in both Figures 1 and 2. It can also be seen that as the chlorophyll content increases, the carotenoid content decreases.

\section{CONCLUSIONS}

In our research, we investigated the effect of three poultry manure pellets on humus sandy soil using the sunflower test plant. In the present study, we examined the effect of average root and stem length, wet biomass, and total chlorophyll and carotenoid content (by destructive and non-destructive methods). There are significant differences in mean root and stem length between control and pellet-treated plants. The $\mathrm{P}+\mathrm{K}$ " $\mathrm{C}$ " $400 \mathrm{~kg} \mathrm{ha}^{-1}$ stands out among the treatments, although there are no differences in wet biomass weights between treated and control plants. In the development of chlorophyll and carotenoid content, higher dose treatments $\left(400 \mathrm{~kg} \mathrm{ha}^{-1}\right)$ had a positive effect on the chlorophyll content of plants, thus increasing the photosynthetically active leaf area. We also proved by spectral studies that sunflower reacts positively to products with higher doses and more nutrients. The reflectance of plants treated with $\mathrm{P}+\mathrm{K}$ " $\mathrm{C}$ " product was low at both $200 \mathrm{~kg} \mathrm{ha}^{-1}$ and $400 \mathrm{~kg} \mathrm{ha}^{-1}$, as in the VIS and NIR wavelength ranges. Based on all this, we recommend the $\mathrm{P}+\mathrm{K}$ " $\mathrm{C}$ " treatment of $400 \mathrm{~kg} \mathrm{ha}^{-1}$ on humus sand soil, because this treatment had the best effect on the development of the examined parameters.

\section{ACKNOWLEDGEMENTS}

I would like to thank the Baromfi-Coop Ltd.for providing the base material for our experiments. This research was supported by EU grant to Hungary; GINOP 2.2.1.-15-2017-00043.

\section{REFERENCES}

Agrárgazdasági Kutató Intézet (AKI). (2012) Baromfi ágazat helyzete piaci kilátásai rövid és középtávon. https://www.aki.gov.hu/publikaciok/kuldes/a:531/Baromfi+\%C
3\%A1gazat+helyzete+piaci+kil\%C3\%A1t\%C3\%A1sai+r\%C3 \%B6vid+\%C3\%A9s+k\%C3\%B6z\%C3\%A9pt\%C3\%A1von

Bencze, G.-Futó, Z. (2017): A kukorica relatív klorofill tartalma, levélterülete és termésátlaga közötti összefüggés vizsgálata 
monokultúrás tartamkísérletben. Jelenkori társadalmi és gazdasági folyamatok, XII. évfolyam, 3. szám, pp. 21-28.

Bökfi, K.-Nagy, A.-Riczu, P.-Gyug, N.-Petis, M.-Blaskó, L.Tamás, J. (2016): Húsliszt és hemoglobin vértermék jellemzőinek nem invazív módszerekkel történő értékelése a VIS-NIR hullámhossz tartományban. Agrártudományi közlemények, 2016/69.

Brake, J.D. (1992): A Practical Guide for Composting Poultry Litter, MAFES Bulletin, p. 981.

Bratek, Z.-Fodor, F.-Király, I.-Nyitrai, P.-Parádi, I.-Rácz, I.Rudnóy, Sz.-Solti, Á.-Szigeti, Z.-Tamás, L. (2013): A növényi anyagcsere élettana. Eötvös Lóránd Tudományegyetem. TÁMOP-4.1.2 A1 és a TÁMOP-4.1.2 A2 könyvei.

Droppa, M.-Erdei, S.-Horváth, G.-Kissimom, J.-Mészáros, A.Szalai, J.-Kosáry, J. (2003) Növénybiokémiai és élettani gyakorlatok. Budapesti Közazdaságtudományi és Államigazgatási Egyetem. Budapest. p. 88.

Foged, H.L.-Xavier, F.-August, B.B.-Jordi, P.-Magri, A.-Schelde, K.M. (2011): Inventory of manure processing activities in Europe. Technical Report No. I concerning "Manure Processing Activities in Europe" to the European Commission, DirectorateGeneral Environment. pp. 138.

Georgakakis, D.-Krintas, Th. (2000): Optimal use of the Hosoya system in composing poultry manure. Bioresource Technology. 72(3): 227-233.

Haga, K. (1999): Development of composting technology in animal waste treatment - review. Asian - Australian Journal of Animal Science 12 (4), 604-606.

Hoffmann, S. (2008): A talaj szervesanyag tartalmának értékelése. Agro Napló 2008/7. https://www.agronaplo.hu/szakfolyoirat/2008/07/szantofold/atalaj-szervesanyag-tartalmanak-ertekelese

$\mathrm{I}_{1}$ : http://bio-fer.hu/ (Download: 16, November 2019)

Kopsell, D.A.-Kopsell, D.E.-Curran-Celentano, J. (2007): Carotenoid Pigments in Kale are Influenced by Nitrogen Concentration and Form. Journal of the Science of Food and Agriculture. 87 (5)
Lichtenthaler, H.K.-Wellbum, A.R. (1983): Determinations of total carotenoids and chlorophylls $\mathrm{a}$ and $\mathrm{b}$ of leaf extracts in different solvents. Biochem Soc. Trans. 603: p. 591-592.

Loch, J.-Nosticzius, Á. (2004) :Agrokémia és növényvédelmi kémia. Mezögazda Lap- és Könyvkiadó Kft. p. 408.

Michel, F.C.-Forney, L.J.-Huang, A.J.F.-Drew, S.-Czu Prenski, M.-Lindeberg, J.D.-Reddy, C.A. (1996): Effects of tuning frequency, leaves to grass mix ratio and windrow vs pile configuration ont he composting of yard trimmings. Compost Science and Utilization 4:26-43.

Michéli, E.-Fuchs, M.-Gál, E.-Simon, B.-Szegi, T. (2011): Talajvédelem. Szent István Egyetem. p. 95.

Nagy, A.-Fórián, T.-Tamás, J. (2012): Fejlett környezetállapotértékelési eszközök alkalmazása gyümölcskultúrákban. Agrártudományi Közlemények 49:221-225.

Nagy, L. (2017): Napraforgó hibridek eltérő válaszreakciói baktériumalapú biotrágya-kezelések hatására. Doktori értekezés tézisei. Debreceni Egyetem, Kerpely Kálmán Doktori Iskola. Debrecen. p. 31.

Pirkó, B.-Tóth, T. (2017): Hogyan tartható fenn a talaj termékenysége állati eredetü szerves trágya nélkül? Agro Napló 2017/2. https://www.agronaplo.hu/szakfolyoirat/2017/02/szantofold/virt ualis-kerekasztal-a-hatekonyabb-termeles-erdekeben

R Core Team (2017): R: A language and environment for statistical computing. R Foundation for Statistical Computing, Vienna, Austria. URL https://www.R-project.org/

Riczu, P. (2015): Spektrális információk alkalmazása a precíziós gyümölcstermesztésben. Kerpely Kálmán Doktori Iskola. Doktori Disszertáció. p. 144.

Tiquia, S.M.-Tam, N.F.Y. (1998): Elimination of phytotoxicity during co-composting of spent pig-manure sawdust litter and pig sludge. Bioresour Technol 65, 43-49. 